\title{
Usaha Meningkatkan Hasil Belajar Revolusi Menegakkan Panji-Panji NKRI dengan Menggunakan Model Pembelajaran NHT pada Siswa XI MIA SMA Negeri 2 Tambun Utara \\ Oleh: \\ Rita Yulismar
}

SMA Negeri 2 Tambun Utara

\begin{abstract}
Abstrak
Salah satu tindakan yang dilakukan pemerintah untuk meningkatkan mutu pendidikan adalah dengan melakukan perubahan paradigma yaitu perubahan orientasi pembelajaran menjadi pembelajaran yang berpusat pada peserta didik. Dalam pembelajaran ini, guru diharapkan menjadi fasilitator yang memfasilitasi peserta didik dalam belajar, dan peserta didik harus aktif belajar dari berbagai sumber belajar dan bekerjasama dengan temannya. Salah satu model pembelajaran yang dapat diterapkan adalah model pembelajaran NHT (Number Head Together).

Rumusan masalah penelitian ini adalah apakah penggunaan metode NHT dalam pembelajaran Sejarah materi Revolusi Menegakkan Panji-Panji NKRI dapat meningkatkan minat dan hasil belajar XI MIA 1 SMA Negeri 2 Tambun Utara, kecamatan Tambun Utara, kabupaten Bekasi, Jawa Barat.

Hasil penelitian ini dapat disimpulkan bahwa penerapan model pembelajaran $N H T$ dapat meningkatkan hasil pembelajaran Revolusi Menegakkan Panji-Panji NKRI di kelas XI MIA 1 SMA Negeri 2 Tambun Utara, kecamatan Tambun Utara. Hal ini dapat ditunjukan dengan meningkatnya jumlah siswa yang tuntas belajar dari 18 siswa atau 42,86\% pada pra siklus menjadi 29 siswa atau 69,05\% pada siklus I dan 41 siswa atau 92,86 \% pada siklus II.
\end{abstract}

Kata kunci : hasil belajar, model pembelajaran NH, siswa SMA N 2 Tambun Utara

\begin{abstract}
One of the actions taken by the government to improve the quality of education is to make a paradigm shift that changes the orientation of learning into learning centered on learners. In this lesson, teachers are expected to be facilitators who facilitate learners in learning, and learners must actively learn from various learning sources and work with their friends. One model of learning that can be applied is the learning model NHT (Number Head Together).

The formulation of this research problem is whether the use of NHT method in learning History of Revolution's material Enforcing Panji-Panji NKRI can increase interest and learning outcomes XI MIA 1 SMA Negeri 2 Tambun Utara, North Tambun district, Bekasi district, West Java.

The results of this study can be concluded that the implementation of NHT learning model can improve the learning outcomes Revolusi Upholding Panji NKRI in class XI MIA 1 SMA Negeri 2 Tambun Utara, North Tambun district. This can be shown by the increasing number of students who complete the study of 18 students or $42.86 \%$ in pre cycle to 29 students or $69.05 \%$ in cycles I and 41 students or $92.86 \%$ in cycle II.
\end{abstract}

Keywords: learning outcomes, $\mathbf{N H}$ learning model, $\mathbf{N} 2$ Tambun Utara high school students 


\section{Pendahuluan}

Salah satu tindakan yang dilakukan pemerintah untuk meningkatkan mutu pendidikan adalah perubahan orientasi pembelajaran yang berpusat pada peserta didik. Dalam pembelajaran yang berpusat pada peserta didik, guru diharapkan menjadi fasilitator yang memfasilitasi peserta didik dalam belajar, dan peserta didik yang harus aktif belajar dari berbagai sumber belajar (Suprdijono, 2009). Proses pembelajaran sepenuhnya diarahkan pada pengembangan ranah afektif, kognitif dan psikomotorik secara utuh/holistik, Dengan demikian dapat melahirkan kualitas pribadi yang siap, pengetahuan, dan keterampilan. Salah satu metode pembelajaran yang dikembangkan $d$ adalah model kooperatif dengan berbagai variasi, yaitu : jig saw, STAD, GI, TPS dan NHT.

Pada umumnya, Guru mengajar Sejarah dengan menjelaskan secara singkat sambil menulis di papan tulis kemudian diakhir pertemuan siswa diberi soal untuk dikerjakan. Berdasarkan pengalaman yang dialami peneliti dalam pembelajaran di kelas XI Mia SMA Negeri Tambun Utara, pada pembelajaran Sejarah ternyata hasil evaluasi belajarnya masih kurang optimal. Sebagaimana yang peneliti alami selama ini, di kelas XI MIA SMA Negeri 2 Tambun Utara khususnya, masih mengalami beberapa permasalahan. Permasalahannya antara lain : (1) sebagian besar siswa masih terlihat belum terlibat aktif dalam pembelajaran, (2) kurangnya motivasi siswa dalam pembelajaran, (3) pembelajaran masih kurang menarik, (4) kemampuan hasil belajar Sejarah siswa masih rendah. Hal ini terlihat dari hasil belajar siswa masih banyak yang dibawah nilai Kriteria Ketuntasan Minimal (KKM) yang ditetapkan sekolah sebesar 74. Dari data hasil belajar siswa pokok bahasan sebelumnya didapat bahwa $57,14 \%$ siswa masih dibawah nilai KKM.

Melihat hasil tersebut, maka perlu dilakukan suatu pembaharuan dalam pembelajaran Sejarah yang bertujuan agar kualitas pembelajaran dan hasil pembelajaran Sejarah meningkat. Peneliti merencanakan perbaikan permasalahan dengan menerapkan metode kooperatif tipe NHT pada pembelajaran Sejarah. Diterapkannya metode ini dengan pertimbangan bahwa metode ini, menuntut siswa berkerja sama dengan teman lainnya dalam kelompok untuk bekerja sama sehinga dapat terlibat total dalam pembelajaan serta mendiskusikan materi untuk mempertimbangkan jawaban yang paling tepat (Lie, 2004:59). Metode ini dilaksanakan dengan cara setiap siswa dikelompokan, diberi nomor di kepala, diberi tugas kelompok, berdiskusi, kemudian secara acak guru memanggil nomor siswa untuk menjawab pertanyaan guru ataupun mengklarifikasi pernyataan teman kelompok lain (Hamdani, 2010:89). Dengan demikian, diharapkan setiap anggota kelompok siap untuk mengemukakan solusi dari setiap permasalahan yang disampaikan guru. Dengan demikian diharapkan penerapan metode NHT dapat mengatasi permasalahan di kelas XI Mia 1 SMA Negeri 2 Tambun Utara, kecamatan Tambun Utara, kabupaten Bekasi, Jawa Barat.

\section{Metode Penelitian}

Penelitian ini menggunakan rancangan Penelitian Tindakan Kelas (PTK). karena Penulis ingin meningkatkan kemampuan pembelajaran secara khusus dalam hal peningkatan hasil belajar Revolusi Menegakkan Panji-Panji NKRI khususnya XI MIA 1 SMA Negeri 2 Tambun Utara, kecamatan Tambun Utara, kabupaten Bekasi, Jawa Barat. Subjek sekaligus objek penelitian ini adalah siswa 
kelas XI MIA 1 SMA Negeri 2 Tambun Utara sejumlah 42 siswa yang terdiri dari 23 siswa perempuan dan 19 siswa laki-laki. Kegiatan penelitian dilakukan pada saat proses pembelajaran Sejarah semester II tahun pelajaran 2016/2017, pada JanuariApril 2017. Teknik pengumpulan data menggunakan tes dan observasi yang dilakukan pada saat proses pembelajaran berlangsung.Tes dianalisa dengan menggunakan nilai individu, nilai rata-rata siswa, dan kriteria ketuntasan belajar berdasarkan penilaian pada acuan dan patokan Sedangkan data observasi digunakan untuk merefleksikan siklus yang telah dilakukan. Penelitian tindakan kelas ini berhasil jika aktivitas siswa dalam pembelajaran masuk dalam kategori baik, nilai rata-rata hasil belajar siswa $>74$ dan persentase ketuntasan siswa $>75 \%$.

\section{Hasil dan Pembahasan}

\section{Perencanaan}

Lembar observasi digunakan untuk mengamati jalannya proses pembelajaran dari aspek afektif dan psikomotorik. Sedangkan alat evaluasi berguna untuk memantau kemajuan hasil belajar siswa dalam aspek kognitif. Ada enam macam indikator yang digunakan dalam observasi yang masing-masing terdiri dari empat deskriptor. Aspek afektif menggunakan indikator mempersiapkan diri mengikuti pembelajaran, memperhatikan penjelasan guru, menyimpulkan dan refeksi kehidupan sehari-hari, dan proses evaluasi, sedangkan aspek psikomotorik terdiri dari dua indikator yaitu, bekerja dalam kelompok NHT dan menanyakan hal yang belum dipahami. Evaluasi untuk memantau aspek kognitif menggunakan evaluasi individu di akhir tiap siklus.

\section{Pelaksanaan}

Pembagian kelas menjadi tiga kelompok menggunakan metode teknik acak berstrata, yaitu kelas dibagi secara heterogen berdasarkan kepandaian, jenis kelamin, suku, agama dan lain-lain kemudian secara acak siswa diambil untuk membentuk kelompok (Nurhadi, 2004 : 69). Pengelompokan seperti ini dimaksudkan agar kelas terbagi secara homogeny yang secara kualitatif dan kuantitatif kemampuan kelima kelompok tersebut adalah sama. Pemberian nomor kepala yang berbedabeda dari 1-5 yang merupakan salah sat ciri khas dari NHT. Pemberian nomor di kepala dan nama kelompok menjadi alternative nama yang melekat pada diri siswa dan memudahkan guru untuk memanggil secara acak siswanya. Penjelasan mengenai materi dilakukan guru dengan metode ceramah, dan contoh di papan tulis serta meminta keterlibatan siswa. Hal ini dilakukan oleh guru agar siswa lebih siap untuk memulai dan memasuki tahapan selanjutnya, walaupun penguatan dan pendahuluan telah dilakukan sebelumnya. Perbedaan antara siklus I dan II yaitu, pada siklus I guru sekaligus peneliti masih ragu untuk melaksanakan langkah ini karena langkah ini merupakan langkah inti awal memasuki model pembelajaran NHT. Namun pada siklus II sudah lancar.

Lembar kegiatan siswa (LKS) dibagikan kepada tiap kelompok agar siswa secara aktif berdiskusi dalam kelompok untuk menyelesaikan masalah. Pemberian LKS ini bertujuan agar siswa lebih terfokus dalam pembelajaran, sedangkan guru membimbing siswa untuk menyelesaikan tugasnya. Apabila kelompok telah selesai menyelesaikan tugasnya, maka guru akan menanyakan tugas tersebut kepada anggota, apakah penyelesaian itu sudah dapat dipahami oleh semua anggota atau belum. Pada siklus I belum semua anggota mengerti dan mau berpartisipasi sehingga proses pembelajaran tidak lah berhasil, namun pada siklus II sudah. Pemanggilan secara acak memiliki beberapa tujuan diantaranya memberikan wahana bagi siswa agar dapat berbicara di depan orang banyak, memberikan penghargaan ke semua orang bahwa mereka punya hak yang sama untuk tampil dan memberikan suatu tekanan agar semua siswa mempersiapkan diri untuk presentasi. Pada siklus I tidak semua siswa siap untuk presentasi, namun pada siklus II, dengan semakin biasanya guru dan siswa terhadap model ini, maka kesiapan siswa 
juga lebih tinggi.

Pemanggilan nomor yang sama untuk menanggapi presentasi teman bertujuan agar kelompok lain selalu menanggapi dan menghargai yang sedang berbicara di depan, namun pada kenyataannya hanya yang bernomor samalah yang konsentrasi terhadap isi paparan presenter. Namun hal itu terjadi hanya di siklus I, ketika di siklus II, dengan diacaknya nomor dan kelompok yang menanggapi, maka situasi berubah, dari yang semula hanya yang bernomor sama, kini menjadi semua kelompok konsentrasi mendengarkan paparan. Klarifikasi terhadap paparan presenter dan tanggapan kelompok lain dilakukan agar masalah (soal yang ada di LKS) dapat terselesaikan dengan baik dan benar bukan sebagai ajang saling menyalahkan. Klarifikasi dilakukan oleh guru bersama seluruh siswa agar proses pembelajaran dapat mencapai tujuan pembelajaran dengan baik dan benar. Kemudian siswa melaksanakan evaluasi hasil belajar.

Pengamatan

Hasil observasi pada pelaksanaan tindakan siklus I dan II menunujukan adanya peningkatan minat siswa untuk mengikuti proses pembelajaran, memperhatikan guru, bekerja dengan kelompok, bertanya dalam pranel, menyimpulkan dan merefleksikan dalam kehidupan sehari-hari, dan kondusifnya pelaksanan evaluasi, sebagaimana tertuang dalam grafik berikut:

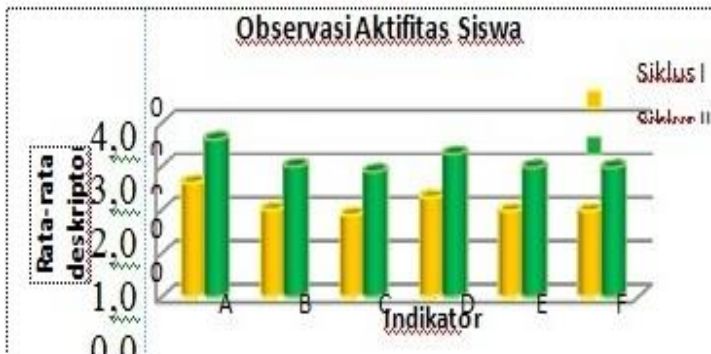

0,0

\section{Keterangan indikator:}

A. Mempersiapkan Pembelajaran

B. Memperhatikanpenjelasanguru

C. Bekeria dalamkelompok tipeNHT

D. Menanvakanhal yang belum dipahami

E. Menvimpilikan dan retieks ternadap

kehiduransehan-han

F. Evaluasi

\section{Gambar 1. Diagram batang observasis siswa}

Semakin banyaknya perolehan siswa yang mempersiapkan pembelajaaran menunjukan bahwa minat siswa terhadap pembelajaran semakin tinggi, tingginya kesiapan ini menunjukan bahwa proses pembelajaran dengan menggunakan NHT lebih menarik dibanding dengan proses pembelajaran konvensional. menempatkan siswa ke dalam kelompok NHT. Hal ini sesuai dengan pendapat Rusman (2012:85) yang menyatakan bahwa penggunaan variasi dalam kegiatan belajar bertujuan mengatasi kejenuhan dan kebosanan siswa karena pembelajran yang monoton, dengan mengadakan variasi diharapkan pembelajaran lebih bermakna dan optimal, sehingga siswa senantiasa menunjukan ketekunan, antusiasme serta penuh partisSejarahsi dalam kegiatan pembelajaran. Tingginya motivasi siswa untuk belajar juga mempengaruhi terhadap tingginya perhatian siswa untuk memperhatikan penjelasan guru, karena dua kemungkinan, yaitu persiapan untuk menyelesaikan tugas diskusi kelompok dan untuk presentasi di tengah KBM. Penjelasan guru mengenai materi untuk menyelesaikan LKS yang dibagikan ke kelompok mengharuskan setiap siswa memberikan kontribusi positif kepada kelompoknya, apabila dia tidak memberkan kontribusi maka anggota kelompoknya akan kurang suka. Hal ini terjadi ketika sikus I berlangsung. Dengan adanya sisklus II 
maka kejadian tersebut dapat dihindari yakni dengan lebih memperhatikan penjelasan guru. Naiknya indicator ini dapat dilihat pada diagram diatas.

Kenaikan indicator bekerja dalam kelompok tipe NHT juga terjad karena siswa akan belajar aktif kalau rancangan pembelajaran yang di susun guru mengharuskan siswa melakukan kegiatan belajar, secara aktif ( Wahid 2010:142). Metode ini mengharuskan setiap siswa untuk berdiskusi kemudian mempresentasikan hasil diskusi ataupun dengan menanggapi presenter. Hal inilah yang membuat siswa menjadi aktif. Kenaikan pada indicator menanyakan hal yang belum di pahami dapat terjadi karena siswa terdorong untuk menguasai materi lebih lanjut agar dapat memperoleh bahan untuk diskusi, ataupun untuk menanggapi presenter. Hal ini merupakan kelebihan NHT seperti yang dinyatakan Rusman (2012:89) bahwa model pembelajaran kooperatif NHT memiliki kelebihan 1) setiap siswa menjadi siap; 2) siswa dapat melakukan diskusi dengan sungguhsungguh; 3) siswa yang pandai dapat mengajari siswa yang kurang pandai.

Indikator menyimpulkan dan refleksi terhadap kehidupan sehari-hari mengalami kenaikan karena dengan adanya proses belajar yang menyenangkan, maka siswa lebih mudah untuk memahami, sehingga dia akan lebih mudah mengaitkan dengan kehidupannya. Indikator proses evaluasipun mengalami kenaikan yang disebabkan semakin memahaminya siswa terhadap materi pembelajaran, sehingga mereka lebih percaya diri untuk mengerjakan evaluasi dengan berbagai konsekuensi.

\section{Refleksi}

Evaluasi hasil belajar pra siklus, siklus I dan siklus II yang dilakukan dalam pelaksanaan perbaikan pembelajaran menggunakan model (NHT) disajikan diagram batang berikut :

\section{Hasil Belajar Prasiklus, Siklus I dan Siklus II}

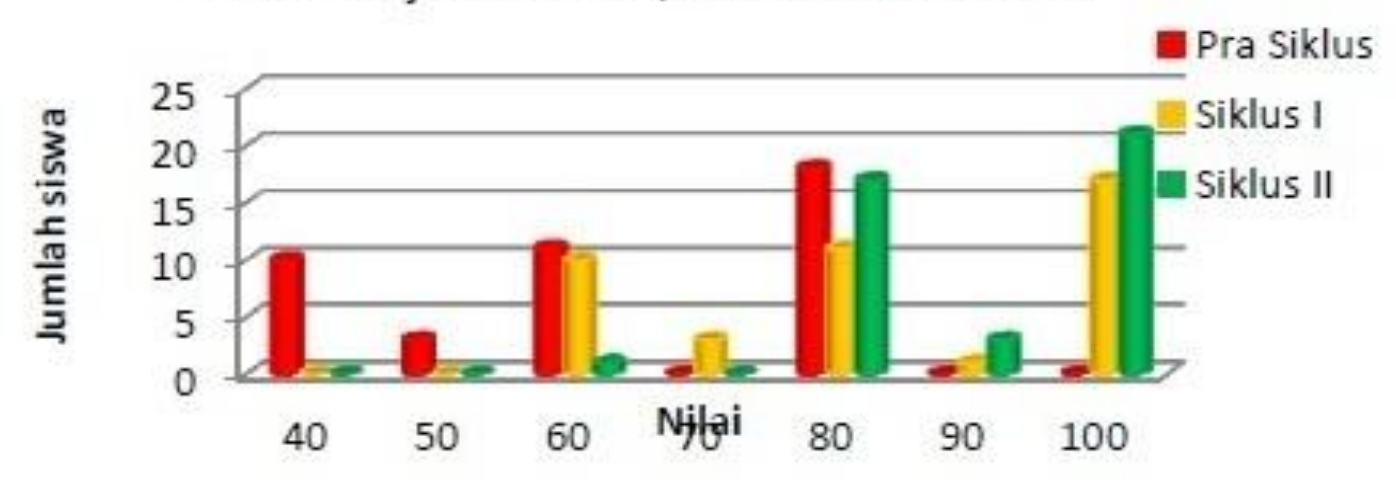

Gambar 2. Diagram batang hasil belajar pra siklus, siklus I dan siklus II

Kenaikan rata-rata nila siswa saat evaluasi belajar dibandingkan tahap sebelumnya maka dapat dikatakan bahwa model pembelajaran NHT dapat meningkatkan minat, motivasi dan hasil belajar XI MIA 1 SMA Negeri 2 Tambun Utara, kecamatan Tambun Utara, kabupaten Bekasi, Jawa Barat.

\section{Penutup}

Berdasarkan hasil dan pembahasan pada bab sebelumnya dapat disimpulkan bahwa model pembelajaran NHT dapat meningkatkan minat, motivasi, aktivitas dan hasil belajar Siswa Kelas XI SMA Negeri 2 Tambun Utara, kecamatan Tambun Utara, kabupaten Bekasi, Jawa Barat. 


\section{Ucapan Terima Kasih}

Dalam kesempatan ini, penulis mengucapkan terimakasih kepada berbagai pihak yang telah membantu terlaksananya penelitian tindakan kelas ini, sejak dimulainya penelitian, penyusunan hasil penelitian dan publikasi .Tidak lupa pula, ucapan terima kasih penulis sampaikan kepada dewan redaksi Jurnal Istoria yang diterbitkan oleh Fakultas Ilmu Sosial Universitas Negeri Yogyakarta atas kesempatan, bantuan dan kerjasamanya yang tidak terhingga sehingga hasil penelitian ini dapat dipublikasikan pada edisi Maret 2017.

\section{Daftar Pustaka}

Arikunto S, 2006. Prosedur penelitian, Rineka Cipta, Jakarta.

Arikunto, S, 2010. Prosedur Penelitian Suatu Pendekatan Praktik, Rineke Cipta, Jakarta. Depdiknas, 2006. Model Pembelajaran Tematik, Puskur, Jakarta.

Dimyati \& Mudjiono, 2006. Belajar Dan

Pembelajaran, Rineka Cipta, Jakarta.

Djamarah, S.B \& Aswan Z, 2007. Strategi Belajar Mengajar, Rineka Cipta, Jakarta. Hamdani, 2011. Strategi Belajar Mengajar. Pusaka Setia. Bandung.

Lie, A, 2004. Cooperative Learning;

Mempraktikkan Cooperative Learning di Ruang-Ruang Kelas, Grasindo, Jakarta.

Nurhadi, Yasin B \& Senduk, A.G, 2004. Pembelajaran Kontekstual (Contextual Teaching and Learning /CTL) dan Penerapannya dalam KBK. UMPRESS ; Malang.

Rusman. 2012. Model-model Pembelajaran Mengembangkan Profesionalisme Guru. Raja Grafindo Persada ; Jakarta.

Sudjana, N, 2005. Metode Statistik, Bandung : Tarrito, Bandung.
Sudjana, N, 2010. Penilaian Hasil Proses Belajar Mengajar, Remaja Rosda Karya, Bandung.

Sukayati, 2008. Penelitian Tindakan Kelas di SD. Pusat Pengembangan dan Pemberdayaan Pendidik dan Tenaga Kependidikan Sejarah, Yogyakarta

Trianto, 2011. Desain Pengembangan

Pembelajaran Tematik (Bagi Anak

Usia Dini \& Anak Usia Kelas

Awal SD/MI), Kencana, Jakarta.

Wahid. 2010. Keterampilan Dasar

Mengajar. Universitas terbuka :

Jogjakarta. 
Volume 12 No 2 Maret 2017 